\title{
Western and East Asian Protection of Human Security
}

\author{
TIMO KIVIMÄKI ${ }^{*}$
}

\begin{abstract}
One of the main trends in the international relations and international security, for the past two decades, has been the new eagerness to intervene into failed and autocratic countries if they fail to protect their own citizens. This trend has distinguished East Asia (including both Southeast and Northeast Asia) from the West. Generally, the distinction has been based on three differences in strategic orientations. First, the role of the military is seen differently in East Asia and the West. Secondly, the role of states as instruments of the protection of civilians is seen differently in the West and East Asia. Thirdly, there is a difference between East Asia and the West regarding to the expected role of the UN Security Council in the authorization of protection. This article investigates the consequences of the three different strategies on human security by reviewing existing literature and by combining new data on discourses of protection with conflict data on various indicators of human survival and welfare. While the Western strategic concept of human security is dominant and hegemonic in the global debate, it seems, on the basis of this investigation, that the East Asian strategy of self-restraint, non-militarism and respect for sovereignty is more effective in the protection of civilians.
\end{abstract}

Keywords: Human Security, Intervention, Responsibility to Protect, East Asia, West, Battle-Related Deaths

*Professor of International Relations, University of Bath, UK;

E-mail: t.a.kivimaki@bath.ac.uk;

DOI: 10.16934/isr.21.1.202006.01 


\section{INTRODUCTION}

One of the main trends in the international relations and international security, for the past two decades has been the new eagerness to intervene into fragile and autocratic countries if they fail to protect their own citizens. This trend has distinguished East Asia (including both Southeast and Northeast Asia) from the West. While East Asian and the West commit to the idea of the promotion of human security and accept that the norm on the responsibility to protect human security is universal, they nevertheless differ in their approaches and nuances in the interpretation of the norm and the strategy (Howe 2019, 184). In this article, "the West" mainly refers to the three Western permanent members of the UN: US, UK and France, while East Asia refers to the entire Northeast and Southeast Asia, but especially to China and Japan.

The approach of the West towards the protection of human security is by no means uniform, with the interventionist US at one end of the spectrum, and more legally oriented UK and France in the middle and Germany at the most militarily hesitant end of the spectrum (Kivimäki 2020a, chap. 5). Neither are East Asian States similar with North Korea (and previously Myanmar) representing the most fanatical line against human rights interventionism, while Japan tends to be much more willing to accept the idea of sovereignty as responsibility (Bellamy and Davies 2009, 549). China's approach is closer to the one of North Korea's while South Korea's concept has been close to the Japanese concept of human security. Yet, one can identify East Asian commonalities, and Western commonalities that differentiate the two regions from one another. Generally, the distinction between the West and East Asia is based on three differences in strategic orientations.

Firstly, the idea of what needs to be done to protect human security differs between the West and East Asia. While the Western great powers have seen military punishments and deterrence against violations of humanitarian norms as a useful tool in the protection of human security (Power 2013, 1-2), East Asian countries have traditionally emphasized prosperity and self-restraint as strategies of human security, and their conception has been that military intervention is almost never helpful for human security (Tase and Takemi 2007, 43-46; Xiaoping 1982, 1).

Secondly, there is a difference between the West and East Asia regarding to the limits of protection of human security. For East Asia, sovereignty of states limits humanitarian protective action more than it does for the West. Also, the role of sovereignty and states as instruments of the protection of civilians is seen differently in the West and in East Asia. While in the West, autocracies and states that are incapable of protecting their civilians are at the core of the problem of human security (Power 2013, 1), East Asian nations tend to be much more 
hesitant to interfere in domestic affairs of other states for the sake of human security. States, for East Asian leaders, are the main instruments of human security of their citizens, and therefore even imperfect states tend to be better for the human security of civilians than the rule of external powers: "when we focus on the security of the human persons, of the individuals, we're making sure that state security and state sovereignty are effectively implemented to help, to protect, to promote the welfare, the well-being and the dignity security of their own people $\cdots$ "(Pitsuwan 2010)

Thirdly, there is a difference between East Asia and the West regarding to the agency of protection. While East Asia has respected the idea of UN-centric action and only participated in UN peacekeeping operations, the US, UK and France have participated in 19 unilateral military operations in 12 different countries during the past two decades, contributing $0.0 \%, 0.7 \%$ and $0.9 \%$ of manpower respectively to UN peacekeeping operations (United Nations Peacekeeping 2020).

This article investigates the approaches and consequences of the two different strategies of human security by analysing documentary sources and reviewing existing literature and by using conflict data on various indicators of human survival and welfare. While the Western strategic concept of human security is dominant and hegemonic in the global debate, it seems, on the basis of this investigation, that the East Asian strategy of self-restraint, non-militarism and respect for the UN and national sovereignty is more effective at protecting human security.

\section{MILITARY OR ECONOMIC MEANS OF THE PROTECTION OF HUMAN SECURITY}

The concept of human security has often been seen in the West as being limited to the doctrine of responsibility of protect. This, again, is often seen as being limited to the prevention of atrocity crimes (Obama 2011, 1055; Power 2013). Yet, human security has emerged as a broader concept. In the international literature it was introduced by the United Nations Development Program UNDP, it is Human Development Report in 1994 (United Nations Development Program 1994, 24-26). There human security was defined as freedom from fear and freedom from want: "There have always been two major components of human security: freedom from fear and freedom from want." (United Nations Development Program 1994, 24).

If we look at US presidential papers from 1989 (Bush et al. 1989), the word "protect" in sentences where the referent objects of cosmopolitan protection are "global strangers" (=people outside the US and US alliances), such 
orientation becomes very clear. Power-centric speech where someone else's behaviour needs to be changed by means of (military) power rather that human security requiring (economic) action by the US itself, was dominant in clauses of cosmopolitan protection in presidential papers in $55 \%$ of the clauses. Those clauses that dealt with the areas that the United States ended up conducting a humanitarian intervention (Kosovo, Afghanistan, Pakistan, Iraq, Somalia, Libya, Syria or Mali), the power centricity of presidential speech varied between 74 and 100 per cent. ${ }^{1}$

If we then look at the US attitude towards the main international normative effort at the cosmopolitan protection, we can see that there, too, United States wanted to focus on a more narrow military concept of protection rather than wanting to focus on the responsibility to protect freedom from want. According to Bolton, the US can accept the responsibility to punish the wrongdoer and intervene in their actions, but they do not want to commit themselves to the nourishment and nurturing of the victims. The latter is the responsibility of the host country: "[W]e agree $\cdots$ that the international community has a responsibility to act when the host state allows such atrocities. But $\cdots$ we thus want to avoid formulations that suggest that the other countries and inhering the same responsibility that the host state has." (Bolton 2005, 1-2) When then Defence Minister Donald Rumsfeld defined the American role in the protection of human security, he too, focused on powerful strategies leaving aside strategies of working directly with those whose security was protected: In Afghanistan primary was task was "denying hostile regimes the opportunity to oppress their ‥ people." (Rumsfeld 2001) As a result of this Western approach that the US represents in its purest form, Mamdani has redefined the acronym R2P as the Western Right to Punish (Mamdani 2010, 53-54).

France and the UK have a much better record of economic assistance and development cooperation than the US. The UK has managed to keep the level of its official development assistance at $0.7 \%$ of its GDP since 2013, while the French ODA has kept under the level of country's commitments at around $0.4 \%$ of the GDP (OECD 2019). Yet, explicit operations to protect civilians and the discourse on protection of "global strangers" (For the concept of "strangers" as the referent object of cosmopolitan protection, see Wheeler 2000) has been kept separate from the aid debate. As a result, military operations and support for military operations in Libya, Syria, Iraq, Yemen, Mali and elsewhere have been focused on changing the behaviour of perpetrators by means of power and force, rather than working directly with victims for their protection. Yet, at least the British military force recognizes the need to combine military operations with economic tackling of grievances, but this has not lead to a systematic coordination of the two: "it will be necessary to adopt a Comprehensive Approach, probably on an international 
scale, as an essential first step in providing assistance which will then need continued monitoring and supervision.” (British Army 2009).

The concept of protection of human security in East Asia is broader and it belongs to the thinking in which security is considered in comprehensive terms. Development was seen as a precondition for security as grievances often created instability. The obsession to develop, rather than tackling political grievances is obvious in the documents of Chinese policies of conflict prevention in the restless provinces of Tibet and Xinjiang (Information Office of the State Council of the People's Republic of China 2009; Information Office of the State Council of The People's Republic of China 1992, chap. 7). Development is seen as a remedy for conflict also in most other East Asian countries (Dan 2007, 31-32).

At the same time, stability and peace were seen as preconditions of economic development, and thus the two are in a mutually constitutive relationship. While in the Japanese security doctrine of Prime Minister Masayoshi Ohira, this thinking was called "comprehensive security"-thinking, President Ramon Magsaysay of the Philippines subscribed to similar ideas and called them "developmental security" (Lansdale 1957, 1; Undated). President Suharto of Indonesia talked about "national resilience" (Lansdale 1959, 1), of which economy was an important part. China's Deng Xiaoping's concept of "security though the four modernizations" (X. Deng 1978; Sinha 2000, 159-60) also included economic elements as a key, while South Korea's former Prime Minister Lee's administration imagined a "Global Korea Vision" with security immersed in development (Park 2000, 307).

The fact that East Asian human security thinking was restricted and limited by the norms of sovereignty has meant that regional security has been created mainly by each nation taking care of its own human security. This way grievance-related threats do not spread as they did in the 1950s and 1960s when communist insurgence spilled over from China, Vietnam, Cambodia and Malaysia to neighbouring and regional countries. Thus, while states are responsible for their own comprehensive security and development in the collective effort at maintaining regional stability, interaction between states is supportive rather than preventive. Countries cannot take responsibility for the development and stability of other countries and so they will have to support rather than undercut the domestic stabilization efforts of other countries. Therefore, the focus of the protection of human security will always remain mainly domestic.

The protection of human security abroad has so far been more modest. Chinese development cooperation has remained under $0.01 \%$ of the country's GDP (AIDDATA 2019), while the GDP-level of official development assistance of rich South Korea and Japan's ODA have also remained low (0.23\% for Japan, and $0.14 \%$ for Korea, see OECD 2019). East Asia's contribution to economic 
human security is, however, more important than official development statistics show. While the Chinese concept of development cooperation emphasises COOPERATION, China tends to focus on projects that produce mutual benefit (Enlai 1964, 1), rather than being involved in charities, let alone in the definition of what is GOOD governance for other countries. This way China avoids meddling in the definition of national priorities of other nations, and yet, in projects of mutual benefit China enables developing countries to make their economy more efficient (Zhang 2009, 121-23). By helping its own economic activities by improving transportation infrastructure in areas it has invested in, China also opens some of the bottlenecks of development in developing countries it operates in (Edinger and Labuschagne 2019). This contribution lifts people from poverty and human insecurity, yet it does not show in China's official development assistance contribution.

The balance between economic and military protection for East Asian countries has emphasized the economic side even in international interaction, given that East Asian countries have not had significant military involvement in the international humanitarian military operations. While Japan and Korea have participated in minor roles in the protection of civilians from terror and dictatorship in Afghanistan, and Korea also in Iraq, China has only participated in the protection of civilians from the terror of Al Qaeda in the Islamic Maghreb, Ansar Dine, al-Merabitun, and other extremist terrorists in Mali. All these participations were in support of the government and related to UN activities.

\section{CONSEQUENCES OF COMPREHENSIVE VS. MILITARISTIC APPROACH}

The development-oriented concept of human security has managed to help transform East Asia from world's most belligerent to one of world's most peaceful region, if we compare regions by looking at conflict fatalities per population (Tønnesson 2009, 112; Hoffman et al. 2018, 49-50). The contribution of comprehensive development-oriented security thinking can be clearly demonstrated by comparing post-World War regimes and the average annual fatalities their countries experienced. Development-insensitive regimes in East Asia have produced more than 300 times higher annual numbers of conflict fatalities than development-oriented regimes (Kivimäki 2014, 101).

In addition to success in reducing the intensity of regional conflicts, development orientation has naturally also increased human security by lifting people from the kind of poverty that fundamentally challenge the security of human individuals. China alone had already lifted over 400 million people out of poverty during the first two decades (1980-2000) of development-oriented 
security thinking (World Bank Undated). Also, Indonesia and Thailand have been considered as model cases of security-oriented poverty alleviation (Rock 2003, 2; World Bank 1998), while the reduction of poverty in the newly industrialized countries (NICs) has been studied extensively as cases of successful poverty alleviation (See for example, Lawler and Seddighi 2001; For a more critical voice, see also Tang 1998).

East Asian lack of global role has traditionally reduced the region's role in the protection of the human security of the "global strangers." However, the expansion of China's economic interaction has produced a lot of mutual benefit with countries of low human security, it has contributed to the lifting of people from poverty, and thus it has reduced human insecurity.

At the same time, elements of Western policies, discursively unrelated to human security, actually increase human security both in the west and abroad. While income inequality in the West is often debated and criticised, the level of poverty in the West is still relatively low. In the USA, where it is higher than in the Western Europe, it is still declining, despite the increase of income inequality. The official poverty rate has gone down for four consecutive years, while the standards of poverty in the West tend to be more stringent than in developing countries (McCarthy 2019).

Western, especially European, development cooperation is also more extensive than development cooperation by anywhere else. Its main objective is poverty alleviation, which makes it a human security policy. However, protection discourse emphasises the question of atrocity crimes, which is just one element of human security policies. In 55\% of the time US president has mentioned the word "protect" as documented by the Presidential Papers of the United States, he has suggested measures that do not restrict America's own violence, or support developmental or other efforts of others, but aims at changing the policy of a threat to human security.

Our data on US discourse and consequences of US protective operations suggest that the discourse that emphasises powerful military means in the protection of human security, is counterproductive. More people tend to die when governments focus on changing the behaviour of others, than when they try to deal with problems by changing their own behaviour. The protection of human security by dealing with economic or environmental problems helps directly, and according to the original definition of human security this is within the realm of human security: "Job security, income security, health security, environmental security, security from crime - these are the emerging concerns of human security all over the world." (United Nations Development Program 1994, 3) The annual number of fatalities of unhealthy environment is 12.6 million (World Health Organization 2018), while hunger kills about 9 million people annually (Mercy Corps 2015). Thus, a focus on broader concept of human security is important. 
Yet, focusing on the economy and the environment, also reduces fatalities of violence. While the calculations on the association between presidential protection speech with the environment as referent object, of the frequency of the word "crime" in presidential speech on the one hand, and fatalities of protective operations on the other, are suffering from the small number of observations ( 25 annual observations of conflict fatalities), the correlations are still very impressive. ${ }^{2}$ However, when we look at the monthly statistics of US protective military operations, the number of observations grows and more reliable statistical conclusions can be drawn. The share of environmental referent objects in presidential clauses on protection has a non-parametric correlation of -0.5486 $(\mathrm{n}=2973, \mathrm{p}<0.00005)$ with the number of US protective military operations. Clearly, militarism in the protection of human security push unilateral protection of civilians to tougher measures and produce more fatalities.

\section{PROTECTION OF HUMAN SECURITY AND THE QUESTION OF SOVEREIGNTY}

The question of level of respect for sovereignty and the norm of non-interference is the clearest difference between the Western and East Asian ways of protecting human security. On the one hand, three Western countries, US, UK and France, utilize the cosmopolitan discourse of global protection of civilians and act in defence of global civilians who are being brutalized by terrorists, criminals and autocrats. In the Western thinking the protection of human security cannot be a hostage of state sovereignty, but instead, sovereignty should be interpreted as something belonging to the people rather than to their regimes. Sovereignty in the Western discourse is often seen as something that involves a responsibility rather than a privilege for the regime (Cohen and Deng 2016; F. M. Deng et al. 1996). Sovereignty for the West implies responsibility to protect the human security of citizens, and if the regime fails in that, the responsibility to remedy the situation lies with the international community.

Such a conception of sovereignty and protection were strengthened especially after the genocides in Rwanda and Bosnia, where inability and unwillingness of the regime to protect civilians caused massive loss of life. After these crises, the failure of Rwanda and Bosnia were repeatedly referred in arguments against a strict respect for state sovereignty, in favour of cosmopolitan concept of protection of civilians regardless of borders (Conflict, Stability and Security Fund, Foreign and Commonwealth Office 2019; Obama 2012). According to PM Tony Blair of the UK: "The Iraqi people deserve to be lifted from tyranny and allowed to determine the future of their country for themselves." (Woolf 2003), while according to President Sarkozy of France the reason for the 
military operation in Libya was the following: "We are doing so to protect civilians from the murderous madness of a regime which, in killing its own people, has lost all legitimacy." (Sarkozy 2011) President George W. Bush of the US crystallized the primary of humanitarian values over the sovereign rights of states and their brutal governments: "The demands of human dignity know no borders and know no boundaries. (G. W. Bush 2003b, 412)

The list of conflicts and countries that Western countries have intervened can be compiled from the Uppsala Conflict Data Program data (Pettersson, Högbladh, and Öberg 2019). If one looks at intra-state conflicts that have become internationalised by the involvement of the US, UK or France, and adds those interferences in which these countries have only used their air forces without sending troops on the ground (in which case Uppsala data does not call it conflict participation), then we can find out that during the past two decades there has been altogether 19 conflicts in 12 countries in which one or several of the three Western superpowers have used force that is not explicitly within the control of the United Nations. Table 1 lists the countries in which these protective military operations have taken place:

TABLE 1. PROTECTIVE MILITARY OPERATIONS

\begin{tabular}{|c|c|c|}
\hline $\begin{array}{l}\text { Main location of battle, years of } \\
\text { operation }\end{array}$ & $\begin{array}{l}\text { Leading actor in military } \\
\text { operation }\end{array}$ & Main target of operation \\
\hline Serbia/Kosovo, 1999 & United States & Serbian government \\
\hline Sierra Leone, 2000 & United Kingdom & $\begin{array}{l}\text { RUF and Sierra Leone } \\
\text { soldiers-turned-rebels }\end{array}$ \\
\hline Afghanistan, 2001- & United States & Al Qaeda, Taliban \\
\hline Pakistan, 2004- & United States & Taliban and Islamist groups \\
\hline Iraq, 2003- (2012 and 2013 excluded) & United States & $\begin{array}{l}\text { Al Qaeda, IS and other Islamist } \\
\text { groups }\end{array}$ \\
\hline Central African Republic, 2006 & France & Union of Democratic Forces for Unity \\
\hline Somalia, 2007- & United States & Al-Shabaab (2007: ICU) \\
\hline Mauritania, 2010 & France & AQIM \\
\hline Libya, 2011, 2016- & $\begin{array}{l}\text { United States, } \\
\text { United Kingdom and France }\end{array}$ & $\begin{array}{l}\text { Government of Libya (2011), IS } \\
\text { (2016) }\end{array}$ \\
\hline Yemen, 2009- & United States & $\begin{array}{l}\text { AQAP (and in 2016, the Houthi } \\
\text { government) }\end{array}$ \\
\hline Mali, 2013- & France, United States & AQIM \\
\hline Syria, 2014- (2017-) & United States & $\begin{array}{l}\text { IS (and covertly, the Syrian } \\
\text { government) }\end{array}$ \\
\hline
\end{tabular}

Abbreviations:

AQAP al-Qaeda in the Arabian Peninsula

AQIM al-Qaeda in the Islamic Maghreb

ICU Islamic Courts Union

IS Islamic State

ISIS Islamic State in Iraq and Syria

RUF Revolutionary United Front 
At the same time, East Asia has been hesitant to engage in human security promotion that could be in clear contradiction with state sovereignty. Studies on East Asian discourse on human security show that the region "is no longer the preserve of Westphalian state-centricity and sovereignty it has often been depicted" (Howe 2019, 210). Yet, states are seen as the main agents in the production of human security rather than the main threats. This is why the East Asian approach focuses more on working with rather than working against states in their approach to the protection of human security. Already before the rise of Western humanitarian interventionism at the end of the 1990s, China was hesitant to accept even UN operations with implications to state sovereignty. Already in 1997, China refused to support (yet did not veto it either) the UN peacekeeping operation in Albania, due to concerns over sovereignty. This was despite the fact that Albania had itself requested the operations. According Chinese UN Security Council representative "the Council should proceed cautiously because the United Nations Charter had stipulated that the Organization should not interfere in the internal affairs of States. The force's deployment should be seen as a special measure taken under special circumstances. But China would not stand in the way of the Council's extension of the force's mandate considering the Albanian Government's request for it." (United Nations Security Council 1997) Afterwards, China has been less hesitant in case military operation is in support of governments against terrorists. In general military diplomacy East Asian countries have been exceptionally self-restrained to use military force against another government in the latter's internal affairs regardless of the intensity of violence used. The East Asian approach has been that even an imperfect state tends to protect its people better than the foreign invaders. If one looks at Uppsala conflict statistics, one can see that such interference has not happened against another East Asian country since 1979 (concluded from data from Pettersson, Högbladh, and Öberg 2019). Before that, after the Second World War, two thirds of East Asian conflict fatalities were produced in conflicts that started out as intra-state conflicts but were internationalized (Calculated from data from Pettersson, Högbladh, and Öberg 2019).

Korea and Japan have participated in the military operation against insurgents in Afghanistan, Korea also in Iraq, but always in support of the host regimes (concluded from data from Pettersson, Högbladh, and Öberg 2019).

In the 2005 World Summit on the Responsibility to Protect, Asian countries have committed to a principle that in theory commits them to the violation of the sovereignty principle (United Nations General Assembly 2005, paras. 138-140). This would be possible if another country is not willing or able to protect the freedom from want and fear of its citizens, if non-intrusive measures have not been successful. Operations that East Asian states could accept, will have to be proportionate and successful in protecting civilians and 
they will have to be decided by a representative institution, the United Nations (more specifically its Security Council), whose members also the protected people and their states are (United Nations General Assembly 2005, chap. V, see also paragraph 77). While among the Western countries the limiting stipulations of the norm of Responsibility to Protect have been interpreted loosely, in East Asia, they are being treated very strictly.

\section{CONSEQUENCES OF RESPECTING SOVEREIGNTY, AND INTERVENTIONS TO PROTECT HUMAN SECURITY}

I have elsewhere shown how the respect for sovereignty and hesitance towards military interference in domestic affairs against another East Asian regime, together with the developmentalist orientation, has contributed to the disappearance of $95 \%$ average annual conflict fatalities in East Asia in the period of 1979- compared to the period of 1946-1978 (Calculated on the basis of data from Pettersson, Högbladh, and Öberg 2019). However, one could assume that the East Asian respect for non-interference gives impunity to violent dictators and increases one-sided authoritarian violence. Yet, evidence about fatalities of authoritarian violence suggests the opposite. When East Asian regimes abandoned military interference in each other's internal affairs they also denied regimes the opportunity to externalise and securitise opposition. If opposition groups could no longer be suspected of meddling with foreign powers, they could no longer be tamped down as security threats. As a result the numbers of fatalities of authoritarian violence have gone down drastically after the beginning in 1979 of the long peace of East Asia (Calculated from Pettersson, Högbladh, and Öberg 2019).

At the same time, the policies of placing transnational norms of responsibility to protect human security before the norms of state sovereignty have produced a lot of human insecurity. On average the number of fatalities increase by $720 \%$ during the first year of Western intervention. The number of average annual conflict fatalities stays $56 \%$ higher during the unilateral Western "protective operation" than during the three years before the intervention. Operations triple the number of fatalities if we compare the average number of fatalities of violence three years before and three years after the unilateral operation (Kivimäki 2020a, chapter 2, Table 2.2). While states without a conflict, or with an uninternationalized intra-state conflict tend to develop, states that host a "protective" Western military operation tend to come out weaker than before the operation. This means in the long run that state's ability to contain opportunistic or criminal violence and protect citizens from it are weakened with Western military operations (Kivimäki 2019a, chap. 4). 
Whether or not military operations have been against, in support or in disregard of the target country's regime also has an impact on the levels and duration of violence and state weakness. Table 2 shows how this affects operations in each of the countries: 4

TABLE 2. EFFECTS OF RELATION OF OPERATION TO THE REGIME

\begin{tabular}{|c|c|c|c|c|}
\hline Country & $\begin{array}{l}\text { For regime, ignoring the } \\
\text { regime or against the regime }\end{array}$ & Duration & $\begin{array}{c}\text { Effect on the } \\
\text { number of fatalities }\end{array}$ & Effect on fragility \\
\hline Libya & Against & No end & Increased a lot & Increased a lot \\
\hline Serbia/Kosovo & Against & Ended & Neutral & Neutral \\
\hline Syria 2013/2014- & Against & No end & Increased a lot & Increased a lot \\
\hline Iraq & Against & No end & Increased a lot & Neutral \\
\hline Afghanistan & Against & No end & Neutral & Neutral \\
\hline Pakistan & Ignoring & No end & Increased a lot & Decreased \\
\hline Yemen & Ignoring & No end & Increased a lot & Increased \\
\hline Somalia & Ignoring & No end & Increased & Decreased a lot \\
\hline CAR & For regime & Ended & Increased & Increased \\
\hline Mauritania & For regime & Ended & Increased & Neutral \\
\hline Mali & For regime & Unclear & Increased & Decreased \\
\hline Sierra Leone & For regime & Ended & Decreased & Neutral \\
\hline
\end{tabular}

If we look at the impact on the durability of internationalized conflicts, we can see in Table 2 that it is difficult to end conflicts if the intervention is conducted against the will of the regime. With the exception of the intervention in Kosovo/Serbia, all such conflicts have failed to end. It has been exceptionally difficult for Western powers to negotiate peace with countries they have had to intervene militarily because of the violent nature of the regime. To justify the use of force against such regimes, they must be demonised. This makes it difficult to initiate dialogue: Western leaders are not rewarded politically for negotiating with demons.

Thus, the East Asian policy of not intervening in domestic conflicts militarily against the regime gets support from the statistics of the association between conflict duration and interventions against regimes.

If we look at the effect on fatalities of interventions that violate state sovereignty, we can see that there are two unclear, neutral cases, where fatalities have not just increased or decreased consistently. In Kosovo fatalities rose 3.5 times during the operation 5 but decreased after the operation had ended. The Yugoslav/Serb regime that the Western intervention fought against was constitutionally scheduled to be changed in elections only two years after the intervention. Even though this case that in table 2 seems unclear of its effect on 
fatalities, seems difficult to justify, especially considering the continuing civilian suffering in Serbia that the exposure to Western depleted uranium munitions continue to result in. In Afghanistan, the number of fatalities has fluctuated during the Western intervention, but it was even slightly higher a few years before it. Fighting had, however, ended in most areas of the country by the latter half of year 2001, before the Western intervention. The main problem with this intervention was, though, that it seems to have prolonged the deadly conflict.

Fatalities were increased during the protective interventions in Iraq and Syria more than anywhere else. In Iraq the increase was from 64 to about 5,000 while in Syria the number of average annual fatalities of war increased with 30,000 people (Calculated from the data on conflicts, non-state violence and one-sided violence: Pettersson, Högbladh, and Öberg 2019; Sundberg, Eck, and Kreutz 2012; Eck and Hultman 2007). In terms of percentages Yemen and Pakistan were also cases where the numbers of fatalities were increased drastically with the unilateral intervention.

In general, it seems that the East Asian hesitance in engaging into interventions is well based not just due to the difficulties of ending conflicts that international protective nations have intervened, but also due to the effect of interventions into fatalities. Furthermore, since non-violent order requires strength of state structures and since interventions tend to erode those structures interventionism is always a dangerous policy.

\section{UNILATERALISM VS. RELIANCE ON THE UN IN THE PROTECTION OF HUMAN SECURITY}

After the failure of the United Nations in Bosnia and Rwanda, the Western focus in cosmopolitan protection turned to the problem of capacity and mandate of protection of civilians. The question of legitimate agency to enforce humanitarian norms was pushed aside. It was simply no longer acceptable for the West that terrorists and dictators continued to harm their citizens in impunity, while the United Nations was unable to act due to lacking resources and later due to the lacking mandate as China (and Russia) took a hesitant stand towards humanitarian interventions.

Individual statements by Western leaders testified to the lack of patience and the need of change even if the United Nations was not yet ready for it. According to UK Prime Minister Tony Blair, the Kosovo war marked the beginning of the new age of human rights enforcement, it was a "battle over the values of civilization" (Blair 1999, 15). According to President Bill Clinton the change in the agency from the UN to the US alliance was dictated by the urgency and the need to save lives: "Make no mistake, if we and our allies do not have the 
will to act, there will be more massacres. In dealing with aggressors in the Balkans, hesitation is a license to kill. But action and resolve can stop armies and save lives." (Clinton 2000, 410) President Obama repeated the same claim about the greater efficiency of US than UN operations more than ten years later when comparing US action in Libya with the UN action in Bosnia: "in just one month, the United States has worked with our international partners to mobilize a broad coalition, secure an international mandate to protect civilians, stop an advancing army, prevent a massacre, and establish a no-fly zone with our allies and partners. To lend some perspective on how rapidly this military and diplomatic response came together, when people were being brutalized in Bosnia in the 1990s, it took the international community more than a year to intervene with air power to protect civilians. It took us 31 days." (Obama 2012, 307-8). Later, of course, Bosnia was left non-violent by the UN after its operation ended in December 2002, while violence continues in Libya after the US, UK and France unilateral regime change. This may have weakened the evidence behind the claim of greater efficiency of Western operations compared to UN operations.

In addition to efficiency, there has been claims by the neo-conservative interventionists of Bush and Trump administration that the UN is also unjustified to make decisions on important matters of peace and war, and that only the United States can make such calls: Commenting on the legitimacy of the UN-led process on Iraq, Secretary of Defence, Donald Rumsfeld claimed that "No UN official, no matter how good, should control decisions of such momentous importance -- peace and war -- for the US." (Rumsfeld 2002). In addition, statements by President Bush suggested that the UN had the responsibility to follow US policies in order to be relevant: In a report of his communications with UN officials President Bush reported to the Congress that he had told the UN 'You can be an effective body to help us keep the peace, or you can be the League of Nations." (G. W. Bush 2003a, 1733 italics added)

The change from UN-centred to unilateral in Western discourse on global protection of human security was visible for quantitative analysis of US presidential papers (G. H. W. Bush et al. 1989). It is possible to calculate from the data on US presidential that analyses sentences where the word "protect" appears in presidential papers that the agent of protection changed after the UN failures in Bosnia and Rwanda. ${ }^{6}$ Clauses in which the agent of protection is representative in the sense that protection is conducted by an agent that the target of protection belongs to (such as the UN) declined from 30\% (1989-1999) to less than ten per cent $(9.7 \%, 2000-)$. This change took place between 1995 (after Rwanda and Bosnia) and 1999 (before the first unilateral operation in Kosovo).

At first the unilateral agency was defined in confusing terms, to hide the Western agency in it. Yet, coalitions of the willing were presented in domestic debates as US or NATO-led coalitions. Domestically, the agency of the West was 
important: "For the first time, (NATO) military commanders on the ground in Bosnia have been given operational control over such actions, paving the way for fast and effective NATO response" (Clinton 1996, 1254). Yet Western agency was still seen as legitimate and representative of the whole world "we must work with our allies to protect innocent civilians, to strengthen the United Nations mission, to bring NATO's military power to bear if our warnings are defied, and to aggressively pursue the only path that will end the conflict, one that leads to a negotiated peace." (Clinton 1996, 1254) In the first unilateral Western operation to protect "global strangers" in Kosovo, the actor was an "International Security Force." The name suggested a global ownership, yet, it was not authorized by the UN Security Council or any other global agency. Again the trend of confusing, yet unilateral agency, can be shown quantitatively by analysing US Presidential Papers: The share clauses about cosmopolitan protection by Western coalitions that were presented as if they also had a global mandate (despite it was not mandated by the UNSC), rose from 5.7\% (1989-1998) to 22\% (1999-). The importance of confusing agency between UN and US-led agency can be seen in the way in which the first operations emphasised this confusing, changeable agency. After a few years there was more tolerance to openly Western coalitions acting more openly in the name global humanity.

The question of the role of the United Nations as the authoriser and agent of global protection of human security is not as unanimous in East Asia as the question of respect for sovereignty and the economic emphasis of human security. After all South Korea and Japan are members of the Western security coalition, and they participated in US-led military operations in Iraq and Afghanistan, while China has been one of the two countries that have prevented the West from getting UN Security Council authority to its military operations. Analysis of the international reactions to the preparatory report by the Commission initiated by Canada on the Responsibility to Protect (International Commission on Intervention and State Sovereignty 2001) reveal that in addition to the lesser willingness of China (and Russia) to accept violations of sovereignty, the role of the UN Security Council was one of the main sticking point between China and the three permanent Western powers in the UN Security Council (Bellamy 2006, 151).

\section{CONSEQUENCES OF UNILATERALISM AND UN-CENTRICITY IN THE GLOBAL PROTECTION OF CIVILIANS}

The consequences of the rise of unilateralism at the end of the 1990s did not instantly show in the statistics of fatalities of protective operations. Unilateral operations in Kosovo and in Sierra Leone were relatively successful, even though 
in Kosovo the number of fatalities increased significantly with the beginning of the operation, as mentioned above.

Later, resistance to Western unilateralism started rising and violent resistance received some of its perceived legitimacy from the unilateral nature of the Western protective operations. Western enemies saw them as rise of neo-colonial (Al Assad 2016b; Gaddafi 2011; Laden 2016; Milosevic 2000a) or imperialist (Gaddafi 2014; Milosevic 2000b) domination rather than as protection of human security. According to Bashar al Assad: "For more than 5 years you [the Syrian Army] have been encountering the fiercest aggressive terrorist attack against Syria standing steadfast in the face of hegemony schemes and the new-old colonialism bids which were foiled at the gates of our pride, power, coherence and steadfastness." (Al Assad 2016a). Soon unilateralist operations started to give rise to the escalation of conflict and to a rise the number of fatalities each time unilateralist operation was started.

Unilateralist discourse was also clearly associated with the felt need to use military force. The share and absolute number of clauses of cosmopolitan protection in Presidential Papers referring to unilateralist ad hoc coalitions was clearly associated with the number of Western protective operations, the number of new Western protective operations and the number of fatalities in Western military operations. The number of clauses with ambiguous agency has a 0.6276 $(\mathrm{n}=47, \mathrm{p}<0.00005)^{7}$ non-parametric (Spearman) correlation with the number of protective American military operations.

Unilateralism also created difficulties in keeping operations focused on cosmopolitan rather than national interests. I have shown elsewhere how, not just the practice, but even the US discourse on protection started focusing on Americans rather than global civilians as the reference object. The great changes took place after the United States was itself targeted by terrorists on 11 September 2001. Clearly, also the East Asian restraint towards unilateral military action seems better justified than the unilateral approach of military protection of human security that the Western great powers had opted for.

If we look at the numbers of fatalities in protective military operations of unilateral and UN agency we can see that comparison goes against unilateral operations. While the average fatalities during Western protective operations increases by $56 \%$ in unilateral operations compared to the three pre-operation years, it declines by $20 \%$ in UN-conducted operations. ${ }^{8}$ Given that here the comparison is not between fatalities of $\mathrm{UN}$ and unilateral operations as such, but between the DEVELOPMENT of fatalities in UN and unilateral operations, we cannot argue against this finding by claiming that unilateral operations were more difficult to start with. Unilateral operations made conflicts considerably more violent, while UN operations made them less violent. Furthermore, if we look at the situations after operations had ended we can see that $63 \%$ of average annual 
violence has disappeared from UN operations, while unilateral operations triple the number of fatalities. Representative UN operations leave countries less violent while unilateral operations leave them more violent. Similar conclusions can be drawn from the comparison of the effects of $\mathrm{UN}$ and unilateral operations on state fragility. While UN operations leave countries more prepared to protect their people, unilateral operations leave states weaker (All calculations on UN discourse and the effect of UN operations, in this article, are based on data from the dataset in Kivimäki 2020b).

\section{CONCLUSIONS}

It seems clear that protection and concern for human security in other countries can be credible only if the protecting states are also interested in freeing foreign civilians from want (Holliday and Howe 2011). If civilians are valuable only when their protection justify violence against their rulers but cease to be valuable when they are begging for economic contributions, there is a contradiction. The consequences of such militaristic protection have not been good for the civilians. In East Asia, using sanctions against North Korea, which have a negative impact on the North Korean population and then claiming the right to protect them militarily would neither be a credible option.

Furthermore, the Western efforts at the protection of global civilians by ignoring state sovereignty have not been very successful. East Asian hesitance in relation to violating the sovereignty of North Korea and Myanmar, therefore, has a solid grounding in the experiences of areas where such hesitance has not been practiced. Violation of sovereignty often intensifies rather than dampens violence, increases the number of fatalities, weakens state capacity to protect its citizens and increases the duration of violent conflict.

East Asia should neither be tempted to follow the West to unilateral humanitarian protection. UN-led operations are not unilateral by definition as the agency of operations is with the entire world. Furthermore, the representation of the Third World nations in the UN, with economic development as the main security challenge, makes UN-led protection less prone to militarism in protection. East Asia should not be tempted simply to "do something" or "to send strong military signals of disapproval" every time there is a humanitarian crisis somewhere. It should feel responsible for the consequences of its own actions rather than actions of others. To produce better consequences, it should continue to follow and strengthen the UN in its efforts to protect global civilians. 


\section{REFERENCES}

AIDDATA. 2019. “China’s Global Development Footprint.” 2019.

https://www.aiddata.org/china-official-finance.

Al Assad, Bashar. 2016a. "Most Able to Encounter Terrorism. Speech by Bashar

Al Assad." http://www.presidentassad.net/index.php?option=com_content\& view=article\&id=1541:most-able-to-encounter-terrorism\&catid=323:2016 \&Itemid $=496$.

Al Assad, Bashar. 2016b. "President Assad's Parliament Speech, June 7, 2016." 2016. http://www.presidentassad.net/index.php?option=com_content\&view= article\&id=1529:president-assad-s-parliament-speech-june-7-2016\&catid= $323 \&$ Itemid $=496$.

Bellamy, Alex J. 2006. "Whither the Responsibility to Protect? Humanitarian Intervention and the 2005 World Summit." Ethics and International Affairs 20 (2): 143-69.

Bellamy, Alex J., and Sara E. Davies. 2009. "The Responsibility to Protect in the Asia-Pacific Region - Alex J. Bellamy, Sara E. Davies, 2009.” Security Dialogue 40 (6): 547-74.

Blair, Tony. 1999. "I Have No Doubt at All That We Will Win... This Is a Battle over the Values of Civilization, Interview." Observer.

Bolton, John. 2005. "Bolton Letter -- International Coalition for the Responsiblity to Protect." http://www.responsibilitytoprotect.org/files/US_Boltonletter_R2P 30Aug05\%5B1\%5D.pdf.

Bush, George H. W., William J. Clinton, George W. Bush, Barack Obama, and Donald Trump. 1989. Public Papers of the Presidents of the United States. Washington D.C.: US Government Printing Office.

Bush, George W. 2003a. "Remarks at a Reception for Gubernatorial Candidate Mitt Romney in Boston, Massachusetts October 4, 2002." In Public Papers of the Presidents of the United States, 2002, Book 2., 1727-35. Washington D.C.: U.S. Government Publishing Office.

Bush, George W. 2003b. "Remarks at the Inter-American Development Bank March 14, 2002." In Public Papers of the Presidents of the United States, 2002, Book 1., 408-12. Washington D.C.: U.S. Government Publishing Office.

Clinton, William J. 1996. "Statement on Vetoing Legislation To Lift the Arms Embargo Against Bosnia August 11, 1995." In Public Papers of the Presidents of the United States 1995, Book 2, 1253-1254. Washington D.C.: US Government Printing Office.

Clinton, William J. 2000. "The President's News Conference March 19, 1999.” In Public Papers of the Presidents of the United States 1999, Book 1, 40921. Washington D.C.: US Government Printing Office. 
Cohen, Roberta, and Francis M. Deng. 2016. "Sovereignty as Responsibility: Building Block for R2P." In The Oxford Handbook of the Responsibility to Protect Edited by Alex J. Bellamy and Tim Dunne, edited by Alex J. Bellamy and Tim Dunne. Oxford: Oxford University Press.

Conflict, Stability and Security Fund, Foreign and Commonwealth Office. 2019. "UK Approach to Preventing Mass Atrocities." GOV.UK. July 16, 2019. https://www.gov.uk/government/publications/uk-approach-to-preventingmass-atrocities/uk-approach-to-preventing-mass-atrocities.

Dan, Yusuke. 2007. "Dan Y. Freedom from Want What Are the Aims of Human

Security." In Strategic Peace and International Affairs Research Institute, Tokai University, Ed., Human Security in the 21st Century., 31-40. Minamiyana: Tokai University Press.

Deng, Francis M., Sadikiel Kimaro, Terrence Lyons, Donald Rothchild, and I. William Zartman. 1996. Sovereignty as Responsibility: Conflict Management in Africa. Washington DC: Brookings Institution Press.

Deng, Xiaoping. 1978. "Realize the Four Modernizations and Never Seek Hegemony." May 7, 1978. http://www.china.org.cn/english/features/dengxiaoping/ 103389.htm.

Eck, Kristine, and Lisa Hultman. 2007. "One-Sided Violence against Civilians in War.” Journal of Peace Research 44 (2): 233-246.

Edinger, Hannah, and Jean-Pierre Labuschagne. 2019. "China's Role in African Infrastructure and Capital Projects | Deloitte Insights.” March 22, 2019. https://www2.deloitte.com/us/en/insights/industry/public-sector/china-inv estment-africa-infrastructure-development.html.

Enlai, Zhou. 1964. "Zhou Enlai Announces Eight Principles of Foreign Aid." 1964. http://www.chinadaily.com.cn/china/2010-08/13/content_11149131.htm.

Gaddafi, Muammar. 2011. "Message From Muammar Gaddafi October 6th, 2011.” LIBYA $360^{\circ}$ ARCHIVE (blog). October 6, 2011. https://libyadiary.wordpress.com/ 2011/10/06/message-from-muammar-gaddafi-october-6th-2011/.

Gaddafi, Muammar. 2011. 2014. "Gaddafi's Last Formal Speech To the People of Libya." NewsRescue.Com. August 10, 2014. http://newsrescue.com/gaddaffislast-formal-speech-people-libyal.

Hoffman, Blake, Paul F. Diehl, Andrew Owsiak, Gary Goertz, and Yahve Gallegos. 2018. "What's So Peaceful about Asian Peace?" Asian International Studies Review 19 (1): 49-73.

Holliday, Ian, and Brendan Howe. 2011. "Human Security: A Global Responsibility to Protect and Provide." Korean Journal of Defense Analysis 23 (January).

Howe, Brendan M. 2019. "Human Security, Peacebuilding, and the Responsibility to Protect in East Asia." Asian Journal of Peacebuilding 7 (2): 183-218.

Information Office of the State Council of The People's Republic of China. 1992. "Tibet -- Its Ownership And Human Rights Situation." Beijing, China. 
http://www.china.org.cn/e-white/tibet/.

Information Office of the State Council of the People's Republic of China. 2009. "White Paper on Development and Progress in Xinjiang." China Daily. http://www.chinadaily.com.cn/ethnic/2009-09/21/content_8717461.htm. International Commission on Intervention and State Sovereignty. 2001. "The Responsibility to Protect: Report of the International Commission on Intervention and State Sovereignty." International Development Research Centre. https://www.idrc.ca/en/book/responsibility-protect-report-international - commission-intervention-and-state-sovereignty.

Kivimäki, Timo. 2014. The Long Peace of East Asia. Farnham/London \& Cambridge MA: Ashgate/Routledge.

Kivimäki, Timo. 2019a. The Failure to Protect. The Path to and Consequences of Humanitarian Interventionism. Cheltenham: Edward Elgar Publishing.

Kivimäki, Timo. 2019b. Coding of US Presidential Discourse on Protection. University of Bath Research Data Archive. doi:10.15125/BATH-00535.

Kivimäki, Timo. 2020a. Protecting the Global Civilian from Violence: UN Discourses and Practices in Fragile Countries. London: Routledge.

Kivimäki, Timo. 2020b. UN Discourse on Protection. A Dataset Based on Computer-Assisted Textual Analysis. Bath: University of Bath Research Data Archive.

Laden, Osama bin. 2016. "Draft Speech About Iran and America With Mahmud's Comments." CIA. https://www.dni.gov/index.php/features/bin-laden-s-book shelf? start $=2$.

Lansdale, Edward G. Undated. "Counter-Guerrilla Operations in the Philippines 1946-1953, Introductory Comments. E.G.Lansdale Papers, Speeches and Writings, Box 12(287)." Hoover Institute Archives, Stanford University, Stanford, California.

Lansdale, Edward G. 1957. "Memorandum on Informal Discussion with Col. Valeriano, Philippine Military Attache, E.G.Lansdale Papers, Speeches and Writings, Box 12(292).” Hoover Institute Archives, Stanford University, Stanford, California.

Lansdale, Edward G. 1959. "Memorandum on Indonesia for the Anderson Subcommittee. E.G.Lansdale Papers, Draper Committee File, Box 34(1232)." Hoover Institute Archives, Stanford University, Stanford, California.

Lawler, K. A., and Hamid Seddighi. 2001. International Economics: Theories, Themes, and Debates. Pearson Education.

Mamdani, Mahmood. 2010. "Responsibility to Protect or Right to Punish?" Journal of Intervention and Statebuilding 4 (1): 53-67. https://doi.org/ 10.1080/17502970903541721.

Mercy Corps. 2015. "Quick Facts: What You Need to Know about Global 
Hunger.” Mercy Corps. March 18, 2015. https://www.mercycorps.org.uk/ articles/quick-facts-what-you-need-know-about-global-hunger.

Milosevic, Slobodan. 2000a. "Closing Address of Slobodan Milosevic at the Fourth SPS Congress." Socialist Party of Serbia. http://www.slobodanmilosevic.org/sps4.htm.

Milosevic, Slobodan. 2000b. "Milosevic: Address to the Nation October 2, 2000." http://www.slobodan-milosevic.org/spch-oc2000.htm.

Obama, Barack. 2011. "Statement on the 15th Anniversary of the Srebrenica Genocide July 11, 2010." In Public Papers of the Presidents of the United States, 2010, Book 2., 1055. Washington D.C.: U.S. Government Publishing Office.

Obama, Barack. 2012. "Address to the Nation on the Situation in Libya March 28, 2011." In Public Papers of the Presidents of the United States, 2011, Book 1., 306-12. Washington D.C.: U.S. Government Publishing Office.

OECD. 2019. "Official Development Assistance (ODA)." The OECD. 2019. http://data.oecd.org/oda/net-oda.htm.

Park, Hahnkyu. 2000. "Comprehensive Security and Regional Nuclear CoOperation Ion East Asia: The Case of South Korea." In Comprehensive Security in Asia Views from Asia and the West on a Changing Security Environment., edited by Kurt W. Radtke and Raymond Feddema eds., 307 -24. London: Brill Academic Publishing.

Pettersson, Therése, Stina Högbladh, and Magnus Öberg. 2019. "Organized Violence, 1989-2018 and Peace Agreements." Journal of Peace Research 56 (4): 589-603.

Pitsuwan, Surin. 2010. "Message from the Secretary-General of ASEAN, H.E. Dr Surin Pitsuwan, for the 'Realizing Human Security in Asia' Symposium at the University of Tokyo. 23 February 2010." Official Website of the ASEAN, Http://Www.Aseansec.Org/24382.Htm. 2010.

Power, Samantha. 2013. "Statement by the US Ambassador to the UN in Her Confirmation Hearing at the US Congress." In 'U.S. Urged to Adopt Policy Justifying Intervention'. The New York Times, edited by Mark Lander.

Rock, Michael T. 2003. "The Politics of Development Policy and Development Policy Reform in New Order Indonesia." SSRN Electronic Journal. https://doi.org/10.2139/ssrn.470082.

Rumsfeld, Donald. 2001. "Text of the Defense Secretary's Briefing on the Military Strikes." The New York Times, October 7, 2001, sec. World. https://www.nytimes.com/2001/10/07/international/text-of-the-defense-se cretarys-briefing-on-the-military.html.

Rumsfeld, Donald. 2002. "Proposed U.N. Security Council Resolution (Draft of 1400, 21 Sep.), Confidential Memorandum.” DNSA collection: Targeting 
Iraq, 1997-2004. https://search.proquest.com/dnsa/docview/1910230434/abstract/ 81DABCAE7DB04C0DPQ/2.

Sarkozy, Nicholas. 2011. "Statement by the President of the Republic at the Paris Summit for the Support of the Libyan People. 19 March." https://www. news24.com/Africa/News/French-warplanes-flying-over-Libya-20110319.

Sinha, Radha. 2000. "The Chinese Economic Development and Security Interests: Implications for Europe." In Comprehensive Security in Asia Views from Asia and the West on a Changing Security Environment., edited by Kurt W. Radtke and Raymond Feddema eds., 159-93. London: Brill Academic Publishing.

Sundberg, Ralf, Kristine Eck, and Joakim Kreutz. 2012. "Introducing the UCDP Non-State Conflict Dataset.” Journal of Peace Research 49 (2): 233-246.

Tang, Kwong-Leung. 1998. "East Asian Newly Industrializing Countries: Economic Growth and Quality of Life." Social Indicators Research 43 (1/2): 69-96.

Tase, Kazuo, and Keizo Takemi. 2007. "Human Security and Japan's Role." In Strategic Peace and International Affairs Research Institute, Tokai University, Ed., Human Security in the 21st Century., 43-59. Minamiyana: Tokai University Press.

Tønnesson, Stein. 2009. "What Is It That Best Explains the East Asian Peace since 1979? A Call for a Research Agenda." Asian Perspective 33 (1): 111 $-36$.

United Nations Development Program. 1994. Human Development Report 1994. New Dimensions of Human Security. New York, NY: UNDP.

United Nations General Assembly. 2005. 2005 World Summit Outcome. Resolution Adopted by the General Assembly 60/1. 2005. A /RES/60/1. New York, NY: United Nations.

United Nations Peacekeeping. 2020. "Troop and Police Contributors." United Nations Peacekeeping. 2020. https://peacekeeping.un.org/en/troop-andpolice-contributors.

United Nations Security Council. 1997. "Security Coucnil Authorizes Extensions of Mandate of Multinational Protection Force in Albania for 45 Days Beginning 28 June.” Press Release SC/6385. https://www.un.org/press/en/ 1997/19970619.SC6385.html.

Woolf, Marie. 2003. "We'll Limit Casualties, Britain Will Tell Iraqis." The Independent, March 18, 2003. https://www.independent.co.uk/news/world/ politics/well-limit-casualties-britain-will-tell-iraqis-111217.html.

World Bank. Undated. Fighting Poverty: Findings and Lessons from China's Success. http://econ.worldbank.org/WBSITE/EXTERNAL/EXTDEC/EXTRES EARCH/0,,contentMDK:20634060 pagePK:64165401 piPK:64165026 t heSitePK:469382,00.html. 
World Bank. 1998. "Indonesia - Education in Indonesia : From Crisis to Recovery." 18651. Washington DC: The World Bank. http://documents.worldbank. org/curated/en/558971468752104023/Indonesia-Education-in-Indonesia-fr om-crisis-to-recovery.

World Health Organization. 2018. "10 Facts on Preventing Disease through Healthy Environments." WHO. March 2018. http://www.who.int/features/ factfiles/environmental-disease-burden/en/.

Xiaoping, Deng. 1982. "We Shall Concentrate On Economic Development. Talk With Kim Il Sung, General Secretary Of The Central Committee Of The Korean Workers' Party." Wordpress.org. https://dengxiaopingworks.wordpress. com/2013/03/08/we-shall-concentrate-on-economic-development/.

Zhang, Tiejun. 2009. "Sino-European Relations: From the Height to the Width." In In Bart Gaens, Juha Jokela and Eija Limnell, Eds., The Role of the European Union in Asia., 121-38. The International Political Economy of New Regionalisms Series. Farnham: Ashgate.

\section{ENDNOTES}

1 All calculations related to the US presidential discourse and its relationship with conflict fatalities or state fragility, in this article, are based on the data at (Kivimäki 2019b). Due to the distribution of the observations, this article uses non-parametric Spearman correlations. The data is produced by NVivo-based coding of all clauses in Presidential Papers with the word "protect" in whichever form. Quantitative data on power-centricity is produced of clauses where the referent object of protection is outside the US and US alliances. A clause is coded as power-centric, if protection is attempted by changing someone else's behaviour (by means of deterrence, persuasion, rewards, etc) instead of changing one's own behaviour (by giving aid, accepting refugees etc. to improve human security of people outside US alliances).

2 The share of the environmental referent object of protection and fatalities $-0.6838(\mathrm{n}=25, \mathrm{p}=0.0002)$, frequency of word "crime" and fatalities of Western military interventions $-0.7722(\mathrm{n}=25, \mathrm{p}<0.00005)$.

3 There are three months during the period, when the president does not use the word "protect" in a foreign policy-relevant manner, and thus the share of "environment" as a referent object of 0 clauses cannot be calculated. This is why the $\mathrm{n}$ is not 300 but 297, even though the number of months investigated was 300, from 1989 to 2013 .

4 Data in Table 2 is from Uppsala conflict data (Pettersson, Högbladh, and Öberg 2019), New War State Fragility Index (Kivimäki 2019b) and (Kivimäki 2020a, 


\section{chap. 2)}

5 Calculations on fatalities here are based on data from (Pettersson, Högbladh, and Öberg 2019).

6 The data is produced by NVivo-based coding of all clauses in Presidential Papers with the word "protect" in whichever form. Quantitative data is produced of clauses that are relevant for US foreign policy. When the referent object of protection is domestic (American) and the threat that protection is needed against is non-intentional, then the clause is classified in the dataset as irrelevant (for example, protection of children from the dangers of tobacco. The only exception to this rule was that the environment was seen so instrumental for human wellbeing that clauses in which the referent of protection is the environment are considered as foreign policy-relevant. In case the referent object is not domestic (the clause does not deal with the protection of the US or Americans or the state of the USA), non-intentional threats do not render the clause irrelevant, as protection of all allies from the dangers of tobacco let alone protection of Somalis from poverty and hunger, can be important foreign (aid) policy objectives.

${ }^{7}$ Here the data is biannual.

8 As always in this article the data on US discourses and the consequences of US protective operations is from (Kivimäki 2019b), while the calculation of the consequence of UN peacekeeping is based on data from (Kivimäki 2020b). 